University of Chicago Law School

Chicago Unbound

Journal Articles

Faculty Scholarship

1970

\title{
Motor Vehicle Air Pollution: State Authority and Federal Pre- Emption
}

David P. Currie

Follow this and additional works at: https://chicagounbound.uchicago.edu/journal_articles

Part of the Law Commons

\section{Recommended Citation}

David P. Currie, "Motor Vehicle Air Pollution: State Authority and Federal Pre-Emption," 68 Michigan Law Review 1083 (1970).

This Article is brought to you for free and open access by the Faculty Scholarship at Chicago Unbound. It has been accepted for inclusion in Journal Articles by an authorized administrator of Chicago Unbound. For more information, please contact unbound@law.uchicago.edu. 


\section{MOTOR VEHICLE AIR POLLUTION: STATE AUTHORITY AND FEDERAL PRE-EMPTION}

\section{David P. Currie*}

7 HE problem of state authority over motor vehicle air pollution was recently highlighted when the Illinois Air Pollution Control Board, for the first time, adopted regulations to deal with vehicle emissions. ${ }^{1}$ Those regulations are disappointingly feeble. Except for outlawing visible smoke and for making it unlawful to dismantle pollution control devices, the new rules do nothing but state that the Board may decide to do something in the future about pollution from automobiles.

In attempting to improve upon these regulations, however, one is struck with a sense of considerable futility. Given the present limits of technology and the necessarily legislative nature of some of the most promising approaches, there is little that an administrative agency could do under even the best conditions. But unfortunately, even this little is partially denied to the agencies by a misguided federal pre-emption provision. That provision appears in the Air Quality Act of $1967^{2}$ and severely restricts the power of the states to deal with this urgent problem. It is the purpose of this Article both to stimulate the abolition of the pre-emption provision ${ }^{3}$ and to explore the areas that are presently open for state regulation.

\section{The Need for State Control of Automobile EXHAUST EMISSIONS}

The automobile, as we know it, not only causes great problems of traffic, accidents, parking, and junkyards; it also spews vast amounts of assorted poisons into the air. It is grossly misleading to say, as industrial polluters are wont to do, that vehicles are responsible for sixty per cent of our air pollution. ${ }^{4}$ Such tonnage comparisons

- Professor of Law, University of Chicago. Member of the Illinois Air Pollution Control Board. A.B. 1957, University of Chicago; LL.B. 1960, Harvard University.-Ed.

While $\mathrm{I}$ make no attempt to disclaim the biases of a state administrator hamstrung by federal law, I do not pretend to speak for the Board in this Article.

1. Illinois Air Pollution Control Board, Rules \& Regulations Governing the Control of AIR Pollution ch. VI (March 25, 1970).

2. 42 U.S.C. \& 1857f-6a (Supp. IV, 1965-1968). See text accompanying note 32 infra.

3. A bill to repeal the pre-emption section has been introduced in the House by Congressman Mikva of llinois. H.R. 16,013, 91st Cong., 2d Sess. (1970).

4. See, e.g., the advertisement published by the Commonwealth Edison Co. in the Chicago Daily News, Dec. 17, 1969, at 35.

[1083 ] 
ignore the fact that some pollutants are worse than others; sulfur dioxide, for example, when coupled with particulate matter, is more than one hundred times as toxic as carbon monoxide. ${ }^{5}$ Nonetheless, the danger from automobile emissions is a significant one. Automobiles have single-handedly ruined the atmosphere of Los Angeles; ${ }^{\boldsymbol{B}}$ and the United States Department of Health, Education, and Welfare (HEW) has indicated that almost every city with a population greater than 50,000 persons has a vehicle pollution problem. ${ }^{7}$

Because of incomplete combustion and evaporation, the internalcombustion engine produces carbon monoxide and unburned hydrocarbons. Because of high temperatures, it oxidizes nitrogen in the air. In addition, the automobile discharges lead and other fuel additives. In the presence of sunlight these several pollutants react in complex ways to produce additional poisons that irritate the eyes, destroy rubber, and can, in sufficient quantities, be very harmful for lungs. Moreover, carbon monoxide can be very dangerous by itself: It has long been a popular suicide tool; the Nazis used it to murder political prisoners; and eight-hour exposure to concentrations not uncommon along metropolitan expressways can destroy the usefulness of up to five per cent of the blood in a human body, with adverse effects on health and judgment. ${ }^{8}$ At least one organic component of automotive smog is strongly suspected to be a cause of cancer. ${ }^{9}$

It might be argued, however, that everything is under control since the federal government has prescribed emission standards for automobiles. ${ }^{10}$ This is an erroneous contention. The federal standards apply only to vehicles manufactured during or after the 1968 model year. ${ }^{11}$ Furthermore, the devices installed to meet those stan-

5. New York has prescribed, largely on the basis of health considerations, onehour maximum ambient air concentrations (to be less than a given value $99 \%$ of the time on an annual basis) of $60 \mathrm{ppm} \mathrm{CO}$ and 0.25 to $0.40 \mathrm{ppm} \mathrm{SO}_{2}$. N.Y. Pub. HeAltr LAW §§ 1271, 1276 (McKinney Supp. 1969); 10 NYCRR § 501, app. 6.

6. See D. Carr, The Breath of Life chs. 5, 10 (1965).

7. Hearings on H.R. 463 Before the Subcomm. on Public Health and Welfare of the House Comm. on Interstate and Foreign Commerce, 89th Cong., 1st Sess. 144 (1965).

8. See Hurn, Mobile Combustion Sources, in 3 Arr Pollutron 55 (2d ed. A. Stern 1968); Stokinger \& Coffin, Biologic Defects of Air Pollutants, in 1 id. 445; Tebbens, Gaseous Pollutants in the Air, in 1 id. 23, 30-33; Agnew, Automotive Air Pollution Research, in 307 Proc. of the Royal Society 153-81 (1968); Staff of Senate Com-

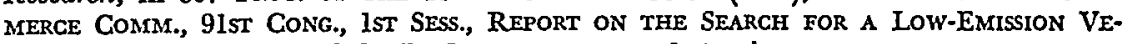
HICLE 2-3 (Comm. Print 1969); D. GARR, supra note 6, passim.

9. HEW, Resume of Air Quality Criteria for Carbon Monoxide (March 1970).

10. Federal standards were first authorized by the Act of Oct. 20, 1965, Pub. L. No. 89-272, tit. I, § 101(8), 79 Stat. 992, codified in 42 U.S.C. \& 1857f-1 (Supp. IV, 1965-1968).

11. 31 Fed. Reg. 5170 (1966); 33 Fed. Reg. 8304 (1968). The 1968 regulations, applicable to 1970 vehicles, are presently found in 45 C.F.R. $\$ \S 85.1-.133$ (1969). 
dards reduce emissions of hydrocarbon and carbon monoxide somewhat, but by no means completely; in a few years the increase in the vehicle population may offset the gains. Moreover, reductions of hydrocarbon and carbon monoxide emissions are achieved by more complete combustion, which tends actually to increase nitrogenoxide emissions. Another inadequacy of the federal law is that there is no federal requirement that the devices be maintained or inspected, even though tests have shown an alarming deterioration in the effectiveness of such devices after they have been on a car while it has traveled a few thousand miles. ${ }^{12}$ Finally, there are no standards at all for lead emissions or even for visible smoke from gasoline-powered engines, and nitrogen oxides are not covered even by the standards for 1970 models.

But, one might say, if the federal program is inadequate, surely the states are to blame for not solving the problem themselves. This, too, is erroneous. It is true that, with the exception of California, the states had done very little about vehicle pollution before the federal government acted in 1965. But that does not justify the decision of Congress, in its wisdom-or more accurately, responsive to the wisdom of the automobile manufacturers-to make it very difficult for the states to do anything about motor vehicle pollution ever again. Just because the auto makers preferred not to have to meet more than one standard, a section of the federal statute now forbids the states, except California, to regulate emissions from new vehicles. ${ }^{13}$

It might be argued that even if pre-emption is removed, the states would be precluded by a lack of the necessary technological expertise from doing anything beyond what the federal government has done to regulate motor vehicle air pollution. But even if present technology permitted no more than the existing federal standards require, there is value in allowing the states to capitalize on new technology as it emerges, rather than making them wait for the

12. See REPORT ON THE SEARCF FOR A LOW-EMISSION VeHICLE, supra note 8, at 4-8.

13. 42 U.S.C. § 1857f-6a (Supp. IV, 1965-1968). The most significant portions of the statute are set out in the text accompanying note 32 infra. The section providing the exception for California reads as follows:

(b) The Secretary shall, after notice and opportunity for public hearing, waive application of this section to any State which has adopted standards (other than crankcase emission standards) for the control of emissions from new motor vehicles or new motor vehicle engines prior to March 30,1966, unless he finds that such State does not require standards more stringent than applicable Federal standards to meet compelling and extraordinary conditions or that such State standards and accompanying enforcement procedures are not consistent with section 202(a) of this title.

42 U.S.C. \& 1857f-6a(b) (Supp. IV, 1965-1968). 
ponderous federal administrative machinery to amend the standards for the whole nation. In addition, there are measures that the murky technology now permits and that the federal regulations do not require. For example, one oil company markets a leadless gasoline in the East and Southeast; ${ }^{14}$ thus, limits on lead emissions are conceivable. Moreover, there is evidence that if the lead were removed from all fuel, it might be possible to require catalytic mufflers which would greatly reduce emissions of hydrocarbons, carbon monoxide, and even nitrogen oxides. ${ }^{15}$ Another example of potential state legislation is a recent California bill-eventually defeated after it had passed one house of the state legislature-that would have banned the sale of internal-combustion engines after 1975.18 One strongly suspects that if such a law were passed, the auto industry would suddenly discover that the obstacles to alternative power systems, such as steam and electricity, are not so insuperable after all. ${ }^{17}$ At the very least the states might regulate visible smoke emissions. Although such emissions are far from the most important vehicle emission problem today, vehicle smoke can be annoying and is not insignificant as a contributor to over-all particulate concentrations. ${ }^{18}$

There are other possible types of state legislation, not all of which are forbidden by federal law. But there is still no excuse for pre-emption. It is inherently improbable that the federal government will prescribe for the whole country standards that are strong enough to protect the air in our most populated cities. In fact, it is not clear that such standards would be desirable in places such as

\footnotetext{
14. See N.Y. Times, March 30, 1970, at 27.
}

15. See Testimony of John O. Logan, President, Universal Oil Products Co., Before the California Assembly Comm. on Transportation, Dec. 4, 1969; AIR \& WATER NEWS, Jan. 5, 1970, at 4; Hurn, supra note 8, at 70-71, 75; R.S. Berry, The Current Status of Automotive Pollution Abatement 5-6 (unpublished, Jan. 1970). The catalyst manufactured by Universal Oil Products has been partially successful even in the presence of lead, and Professor Berry therefore suggests that it might be required in all automobiles even if lead is not removed from gasolines.

16. See Arr \& WATER NEWs, Aug. 4, 1969, at 1 .

17. The rosy picture of steam cars that was painted by the Commerce Committee staff [see REPORT ON THE SEARCH FOR A LOW-EMISSION VEHICLE, supra note 8], has been marred by the announcement by William Lear, one of the leading members of the Committee Staff, that steam does not seem to be a practicable alternative to gasoline. See Arr \& WATER NEWs, Jan. 12, 1970, at 5. At an earlier date, Lear had branded a report that he was giving up on steam as "a misstatement put out by someone in Detroit." See Chicago Daily News, Nov. 20, 1969, at 65, col. 4. Lear has now indicated that he is hoping that the gas turbine will prove satisfactory. AIR \& WATER NEWs, Jan. 12,1970 , at 5 .

18. Studies by the National Air Pollution Control Administration on emissions have estimated that in 1966, vehicles were responsible for $15 \%$ of all particulate emissions in the New York metropolitan area. See HEW, NEW YORK-NEW JERSEY ArR POLLUTION Abatement Activity, Phase II, Pre-Conference Investigations 45 (196\%). 
rural Kansas, where air pollution may not be a significant problem. But the federal authorities have not yet tried to prescribe different standards for different regions, and it is questionable whether they have authority to do so. ${ }^{19}$ Moreover, federal pre-emption stifles creativity by eliminating, except in California, the "laboratory" functions of state and local governments that Justices Holmes and Brandeis were so taken with. ${ }^{20}$ State experimentation led to the federal standards in the first place; thus, Congress has seriously wounded the goose that lays golden eggs. Furthermore, there is always something undesirable about legislation that forbids the states from protecting the health and comfort of their people. Minimum federal standards are admirable, and perhaps indispensable, since the states were not doing the job. But to forbid stricter state standards is inexcusable. Finally, pre-emption is wholly inconsistent with Congress' explicit expectation that the states will prescribe and implement air quality standards for automotive pollutants. ${ }^{21}$ Congress, then, has asked the states to control pollution and simultaneously has deprived them of effective authority to do so.

\section{The Rationale of Pre-emption}

The history of federal concern with automobile air pollution is found in the legislative history both of the National Emission Standards Act, enacted in 1965, and of the 1967 amendments to that Act, which were contained in the Air Quality Act. Although the preemption provision was not enacted until 1967, the 1965 history is pertinent, since several individuals indicated concern at that time with the pre-emption problem.

\section{A. The 1965 Act}

Until 1965, federal statutes for the control of air pollution were silent as to motor vehicle emissions, and there was a general statutory declaration that "the prevention and control of air pollution at

19. See Hearings on Automotive Air Pollution Before the Subcomm. on Air and Water Pollution of the Senate Comm. on Public Works, 90th Cong., 1st Sess. 109 (1967) (testimony of Dean Coston, HEW) [hereinafter Senate Automotive Hearings].

20. Truax v. Corrigan, 257 U.S. 312, 344 (1921); New State Ice Co. v. Liebman, 285 U.S. 262, 311 (1932) (Justice Brandeis, dissenting).

21. 42 U.S.C. \& I857d(c) (Supp. IV, 1965-1968). This subsection authorizes the states to adopt ambient air quality standards applicable to regions designated pursuant to \& 1857c-2 as "air quality control regions," and it provides certain procedures which the state must follow in doing so. The subsection generally provides for cooperation between state and federal officials in setting the proper standards for the various regions. This is consistent with the declaration of $\S 1857 \mathrm{~d}(\mathrm{~b})$, that "municipal, state, and interstate action to abate air pollution shall be encouraged ...." 
its source is the primary responsibility of State and local governments." 22 Relying in part upon a prior version of that provision, the United States Supreme Court in $1960^{23}$ upheld a local ordinance imposing smoke limitations on vessels engaged in interstate commerce: "State regulation, based on the police power, which does not discriminate against interstate commerce or operate to disrupt its required uniformity, may constitutionally stand."24 If it were not for the statutory pre-emption provision enacted in 1967, this decision would provide strong authority for upholding state regulation of vehicle emissions. ${ }^{25}$

In 1965 the Secretary of HEW was first authorized to prescribe "standards, applicable to the emission of any kind of substance, from any class or classes of new motor vehicles or new motor vehicle engines ...."26 Although the authorizing legislation contained no specific mention of the power of the states to regulate the same subject, one reason for federal standards was the desirability of uniformity. The Senate Committee on Public Works stated that "it would be more desirable to have national standards rather than for each State to have a variation in standards and requirements which could result in chaos insofar as manufacturers, dealers, and users are concerned."2t The committee also expressed the hope "that individual States will accept national standards rather than additionally impose restrictions which might cause undue and unnecessary expense to the user." 28 Senator Edmund S. Muskie, responding to a suggestion that the states should be free to set standards stricter than the federal standards, said that such a situation would be "almost impossible" because of the interstate mobility of vehicles. He added: "Do you think a given manufacturer could produce automobiles meeting fifty standards?" 29 However, Harry F. Barr, of the Auto-

22. Clean Air Act \& 101(a)(3), 42 U.S.C. § 1857(a)(3) (1964).

23. Furon Portland Cement Co. v. City of Detroit, 362 U.S. 440 (1960).

24. 362 U.S. at 448.

25. A recent California decision, however, limited state power to regulate smoke from railroad diesel engines. California v. Atchison, T. \& S.F. Ry., 74 Cal. Rptr. 222, 268 Cal. App. 2d 501 (Cal. App. 1968). But that case is distinguishable from the case discussed in the text, for the California decision was based on a finding that compliance with the regulation would be impracticable even in the intrastate context. For cases concerning state power to regulate nonpollution aspects of interstate motor traffic, see Bibb v. Navajo Freight Lines, Inc., 359 U.S. 520 (1959); Maurer v. Hamilton, 309 U.S. 598 (1940); South Carolina State Highway Dept. v. Barnwell Bros., 303 U.S. 177 (1938).

26. National Emission Standards Act § 202, 42 U.S.C. § 1857f-1 (Supp. IV, 1965-1968).

27. S. REP. No. 192, 89th Cong., Ist Sess. 6 (1965).

28. Id. at 8 .

29. Hearings on S. 306 Before a Subcomm. of the Senate Comm. on Public Works, 
mobile Manufacturers' Association (AMA), observed that the statute did not ensure that the states would refrain from imposing additional standards. ${ }^{30}$ Thus, although the 1965 statute was silent on the subject of federal pre-emption, one could plausibly have argued at that time that state regulation was to some extent limited by the authorization for federal standards. ${ }^{31}$

\section{B. The 1967 Act}

Despite the 1965 federal standards, several states proceeded to consider or to enact legislation concerning vehicle emissions. In response to those state activities, Congress clarified the federal policy and explicitly limited state power by adopting, in the 1967 Air Quality Act, a stringent pre-emption provision:

Sec. 208(a). No State or any political subdivision thereof shall adopt or attempt to enforce any standard relating to the control of emissions from new motor vehicles or new motor vehicle engines subject to this subchapter. No State shall require certification, inspection, or any other approval relating to the control of emissions from any new motor vehicle or new motor vehicle engine as condition precedent to the initial retail sale, titling (if any), or registration of such motor vehicle, motor vehicle engine, or equipment.

$$
\text { -... }
$$

(c) Nothing in this subchapter shall preclude or deny to any State or political subdivision thereof, the right otherwise to control, regulate, or restrict the use, operation, or movement of registered or licensed motor vehicles. ${ }^{32}$

As originally introduced, the bill that became the 1967 Act contained no provision for federal pre-emption of state power. ${ }^{33}$ But shortly after the initiation of hearings on the bill before a subcommittee of the Senate Public Works Committee, that subcommittee conducted additional hearings on the automotive problem alone; and in those hearings the issue of state authority to regulate vehicle emissions arose. ${ }^{34}$ Los Angeles County Supervisor Warren Dorn argued that federal law should provide minimum standards and

89th Cong., 1st Sess. 91 (1965). The suggestion was made by Warren Dorn, of the Los Angeles County Board of Supervisors.

30. See Hearings on H.R. 463 Before the Subcomm. on Public Health and Welfare of the House Comm. on Interstate and Foreign Commerce, 89th Cong., Ist Sess. 281 (1965).

31. Cf. Pennsylvania v. Nelson, 350 U.S. 497 (1956).

32. 42 U.S.C. \& 1857f-6a (Supp. IV, 1965-1968).

33. See Senate Automotive Hearings, supra note 19 , at 8.

34. See Senate Automotive Hearings, supra note 19. 
allow stricter state rules where conditions require them. ${ }^{35}$ HEW Deputy Undersecretary Dean Coston, however, argued that "utter confusion" would result if states were permitted to adopt varying standards and that state regulation would be an unnecessary duplication of federal regulation. ${ }^{38}$ The automobile industry, through Thomas Mann of the AMA, reiterated its concern that "a multiplicity of standards could create chaos not only within the industry but in the economy and be harmful to the consumer as well." 37

When the bill emerged from the Senate committee, it contained the pre-emption language of the present statute, reserving the right of the states to regulate vehicle use and allowing California an exemption. ${ }^{38}$ The report explained that this language was a compromise between California's interest in setting "more stringent standards to meet peculiar local conditions" and the auto industry's desire for "a single national standard in order to eliminate undue economic strain on the industry." 39 Only California, the report indicated, had demonstrated sufficiently compelling local circumstances; if other states were to develop such circumstances in the future, Congress should then consider expanding the waiver provision. According to the report, the compromise was beneficial because it would allow California not only to protect its people, but also to serve as a testing ground for new regulations, without exposing the consumer everywhere to additional costs and without subjecting the industry to more than one variation in applicable regulations. ${ }^{10}$

The reasons given for the enactment of the pre-emption provision can be summarized as follows: to protect the manufacturer against having to build engines which would comply with a multiplicity of standards (Senator Muskie); to protect the vehicle owner from having to deal with different standards in each state in which he drives (Senator Muskie); to avoid the unnecessary duplication of

35. $I d$. at 13-14.

36. $I d$. at 107 .

37. Id. at 403 .

38. See note 13 supra.

39. S. REP. No. 403, 90th Cong., 1st Sess. 81 (1967).

40. Id. at 33. After the Senate passed the bill, the House Committee altered the pre-emption section to permit the Secretary of HEW-rather than the state itself-to set special standards for California. That alternation would have reduced the manufacturers' difficulty in complying with two sets of rules, since the two sets would not be separately administered. See H.R. REP. No. 728, 90th Cong., 1st Sess. 21-22, 69 (1967). But in the final bill, as enacted by both houses after a conference to work out differences between the House and Senate versions, the Senate language was reinstated and California was allowed to set her own standards, contingent on the Secretary's finding that waiver of pre-emption was proper. See H.R. REP. No. 916, 90th Cong., 1st Sess. 18 (1967). 
federal standards (Undersecretary Coston); to avoid "unnecessary expense" to the owner (the Senate Public Works Committee); and generally to avoid "chaos" and "confusion" (Thomas Mann, Undersecretary Coston, and the Senate Public Works Committee). Basically, the reasons are rationalizations for protecting the automobile manufacturers from paying the cost of effective pollution control. I do not suggest that the cost of reducing pollution should be ignored. But it does seem that the states can be trusted to consider whether a proposed measure will impose unreasonable burdens on the use of automobiles. The image of Congress is not improved by legislation designed to protect the manufacturers from the risk that states may prize health too highly. Thus, the pre-emption section should be promptly and embarrassedly replaced by a provision explicitly recognizing state and local power to enact regulations more stringent than the federal standards.

In the meanwhile there is a good deal that the states can do, since fortunately federal pre-emption is not complete. In order to explore the limits of permissible state action, it may be helpful to consider the validity of a few specific examples of state regulation.

\section{Validity of Specific Types of State Regulation}

\section{A. Standards Stricter than the Federal}

The federal standard for carbon monoxide emissions from new 1970 vehicles is twenty-three grams per mile; 41 for a state to prescribe a lower standard would be to require "approval relating to the control of emissions from any new motor vehicle . . . as condition precedent to the initial retail sale ..."-a requirement which is plainly forbidden by section 208 of the Act. Such a requirement would compel manufacturers to tailor their products to more than one standard, would duplicate a federal standard on the identical subject, and would impose additional costs on the buyer beyond those required for the identical purpose by federal law. This kind of regulation is exactly what Congress meant to forbid.

A literal reading of the statute, however, suggests that once a vehicle has been transferred to an ultimate purchaser, there are no limits on the state's power to prescribe emission standards as a condition of operation. The pre-emption section speaks only of emissions from "new" vehicles, and "new" vehicles are defined to include only those which have "never been transferred to an ultimate pur-

41. 45 C.F.R. $\$ 85.21$ (1969). 
chaser." 42 But such a reading would completely subvert the purpose of the pre-emption clause, and consequently it seems less than likely that the courts would accept it. ${ }^{43}$

\section{B. Emission Limits on State-Purchased Vehicles}

If a state establishes emission standards for the automobiles which it purchases for state uses, it has technically imposed a standard relating to emissions from new motor vehicles, and its regulation might therefore seem to be forbidden by the Act's pre-emption section. But the state, like any other consumer, presumably is free to buy what it chooses. The vice in state regulation, as Congress saw it, seems to have been not that a customer might decide that he himself preferred low-emission vehicles, but that a state would forbid other customers from purchasing vehicles meeting federal standards. Any policy consideration favoring pre-emption for the protection of the consumer is by definition inapplicable when the state limits only its own purchases.

\section{Required Maintenance and Inspection}

The federal statute clearly permits a state to require that vehicles equipped with control devices certified under the federal statute be maintained in good working order and be inspected annually at the owner's expense. In fact, the states not only have the power to require maintenance and inspection of federally required devices, but they are encouraged and expected to do so. The automobile manufacturers were insistent that state inspection was necessary lest "the failure of the vehicle owner to maintain the emissions control system ... render the entire program useless and wasteful." ${ }^{44}$ Even Mr. Coston of HEW, who argued that even California ought to be preempted from imposing additional emission limits on new vehicles, expressly favored state maintenance requirements:

42. 42 U.S.C. \& 1857f-7(3) (Supp. IV, 1965-1968).

43. See Kennedy \& Weekes, Control of Automobile Emissions-California Experience and the Federal Legislation, 33 LAw \& CONTEMP. ProB. 297, 313 (1968). For this reason, § 6-6.2 of the Illinois regulations, which provides generally that diesel engines not emit smoke which is equal to or "greater than $30 \%$ opacity" was amended before adoption to apply only to vehicles manufactured before January 1, 1970. ILLINoIs AIR Pollution Control board Rules \& Regulations Governing the Control of Air PolLUTION ch. VI, $\S 6-6.2$ (March 25, 1970). The federal standards prescribe $40 \%$ and $20 \%$ capacity for diesel smoke from such vehicles, depending on whether or not the vehicle is accelerating.

44. Hearings on H.R. 463 Before the Subcomm. on Public Health and Welfare of the House Comm. on Interstate and Foreign Commerce, 89th Cong., Ist Sess. 283 (1965) (remarks of Harry F. Barr of GM and AMA). 
Senator Baker. You don't think the doctrine of Federal preemption would prevent the State of California or Los Angeles County from making additional restrictive regulations on the use or the maintenance of automobiles?

Mr. Coston. No sir; not on the use or maintenance; only-

Senator Baker. But it would prohibit the county of Los Angeles on installation of any device as a precondition to the sale of automobiles?

Mr. Coston. I think it should . . . .45

An even stronger indication of the legislative intent may be found in the 1967 Act itself, for one of the provisions of that Act authorized federal grants to state pollution control agencies in order to aid in "developing meaningful uniform motor vehicle emission device inspection and emission testing programs." 46 It is quite clear from the Senate report that this provision was designed to leave inspection to the states:

Federal responsibility under this provision would be to insure the development of appropriate test procedures and, in general, to provide technical assistance.

State's responsibility would be to assume responsibility for inspection of pollution control systems as an integral part of safety inspection programs, which some States now have and others are developing. ${ }^{47}$

An analysis of the policy of the Act also leads to the conclusion that state inspection and maintenance requirements are permissible. No manufacturer is required to comply with multiple regulations, since the states are merely ensuring that the original federal requirement is still met; the federal standards are not being duplicated, but rather are being enforced by the states. The expense to the owner is only that cost which is necessary to maintain the device that was initially required by the federal government; so long as the standard enforced is the uniform federal one, there are no important multiple burdens on owners or operators even if the requirement is not limited to vehicles licensed in the enacting state.

\section{Requiring Compliance with the Federal Standard}

If a state is to require maintenance and inspection, ${ }^{48}$ it must have some standard against which each vehicle can be tested; and it

45. Senate Automotive Hearings, supra note 19 , at 115.

46. 42 U.S.C. \& 1857f-6b (Supp. IV, 1965-1968).

47. S. REP. No. 403, 90th Cong., 1st Sess. 35 (1967).

48. See text accompanying notes $44-4$ stpra. 
appears at first glance that to require adherence to the original federal standard of twenty-three grams of carbon monoxide per mile would be exactly in accord with federal policy.

The federal standard, however, as was frequently pointed out during the hearings, does not require that each vehicle comply. The manufacturer satisfies the requirement if representative samples of each model obtain federal approval, even though individual vehicles of the same type may be either above or below the standard. Consequently, for the states to hold each automobile to the federal standard would be to impose an additional requirement beyond that of federal law and would arguably be illegal. The following colloquy is illustrative:

Senator Muskie. Now if the inspection system is going to be installed it would be applied motorist by motorist. Let us say a motorist bought an old car and was told it had exhaustive device controls on it and he goes in for his annual inspection, if that is what it is, and he is told his car does not meet the standard, that it is 300 . Now what should happen to him at that point? ...

Mr. Misch (of Ford). ... Let me get into the record ... typical items that are being considered as part of that maintenance or inspection.

For one thing, on the air injection systems, the inspection should be made of the positive crankcase ventilation system to determine if it is operational .... On the air injection system we suggest that plumbing connections be checked for tightness at appropriate routing and that plumbing is properly in place. The air pump drive belt should be properly tensioned; idle speeds should be adjusted within proper limits, and ignition timing should be adjusted or checked for proper limits.

-...

Senator Muskie. So to clarify the apparent dilemma of the motorist whose situation I hypothecated a few moments ago, he is not going to be penalized because his car does not have the inherent capacity to meet the California or national standards; all he is required to do or all he would be required to do under the inspection system which you contemplate is a mechanical inspection of his vehicle to insure that it is operating at or near its maximum. ${ }^{40}$

The reason for testing a small sample is not a desire to impose a lax standard; rather, it is the desire to avoid the expense and difficulties that would be involved in testing each vehicle. Thus, if a state should devise a simple means of testing emissions, then requiring each car to meet the federal standard would further, rather than hinder, federal policy. Therefore, the express statutory recognition

49. Senate Automotive Hearings, supra note 19, at 477-79. 
of state inspection systems should be held to permit states to require each vehicle covered by federal standards to meet those standards at any time after initial sale and registration.

\section{E. Provisions Applicable to Pre-1968 Vehicles}

Quite clearly a state may require that 1967 and earlier models be equipped with pollution control equipment. The federal standards themselves apply only to 1968 and later models, and the statute provides for federal standards only for new vehicles, which are defined as vehicles which have "never been transferred to an ultimate purchaser." 50 It is of course conceivable that Congress meant to preclude state regulation even of vehicles exempt from the federal law, but the existence of such a regulatory vacuum is not to be lightly inferred. Moreover, HEW's Dean Coston, who gave the principal testimony in favor of pre-emption, made it clear that he had no intention of forbidding the states to deal with emissions from older cars:

Mr. Coston. . . . The Federal law, however, is totally silent on the question of used cars. So here I think that, even if you apply a full preemption doctrine to the Clean Air Act, the State of California would be free to deal with used cars in different terms.

Senator Muskie. But only because the Federal law does not apply. Mr. Coston. That is correct. ${ }^{51}$

The same point is also clearly made in the Senate report:

While there has been a great deal of concern expressed regarding control of new vehicles little attention has been paid to control of used vehicles, either their emissions or their use. . . . Any significant advance in control of used vehicles would result in a corresponding reduction in air pollution. These are areas in which the States and local government can be most effective. ${ }^{52}$

Thus, the legislative intention is plain with respect to pre-1968 vehicles. Furthermore, state and local controls on the emissions of such vehicles would not violate any of the policies behind the preemption provision. Such regulations would not subject manufacturers to multiple requirements, since these vehicles have long since left the manufacturers' hands; it would not duplicate federal standards, for there are no federal standards for such cars; and it would not result in the unnecessary expense with which the legislators were concerned, because it can hardly be unnecessary to insist

50. 42 U.S.C. § 1857f-7(3) (Supp. IV, 1965-1968).

51. Senate Automotive Hearings, stupra note 19, at 108-09.

52. S, REP. No. 403, 90th Cong., 1st Sess. 34 (1967). 
that all cars be equipped with one control device. Depending on the form of the state regulation, it might or might not impose special burdens on out-of-state drivers. If the state required the attachment of control devices upon the transfer of an older vehicle to a resident of the state, or if it required such attachment when the owner moved to the state, as California does, ${ }^{53}$ or if it required the attachment of an emission control device as a prerequisite to automobile registration in the state, then no driver would be subjected to multiple standards and no out-of-state driver would be inconvenienced. Although a broader regulation forbidding the operation of any pre-1968 vehicle without controls would impose a significant burden on operators from other states, the authority of the Supreme Court decision concerning smoke controls on interstate vessels, ${ }^{54}$ along with the complete absence of federal regulatory authority over pre-1968 vehicles, and along with the explicit statements in the legislative history indicating that states are free to regulate used vehicles, suggest that the states have this broader power as well. ${ }^{55}$

\section{F. Regulation of Types of Emissions Not Referred to in the Federal Act}

It is difficult to determine whether a state may regulate the emission of nitrogen oxide or visible smoke from new gasoline-powered vehicles. On the one hand, the federal statute expressly forbids any state control over emissions from new vehicles; ${ }^{56}$ on the other hand, the philosophy underlying pre-emption seems to be that a manufacturer subjected to federal regulation should not also be subjected to regulation by the states. Since there are not yet any federal standards applicable to the emission of either smoke or nitrogen oxides from new gasoline-powered vehicles, the argument for freedom from state standards is weakened. It seems clear that neither Congress nor the HEW Secretary desired a total absence of standards governing these pollutants; they desired merely to prevent the duplication of federal standards by state standards. Moreover, there is some support in the legislative history for the view that states may regulate emissions which are not referred to in the federal regulations. Thomas Mann of the AMA, in arguing for pre-emption, was asked whether he would like California and other states to be forbidden to regulate

53. Cal. Health \& Safety Code, § 39129 (West Supp. 1970).

54. See note 23 supra and accompanying text.

55. See Kennedy \& Weekes, supra note 43, at 313-14.

56. 42 U.S.C. § 1857£-6a (Supp. TV, 1965-1968). 
nitrogen oxides as well as hydrocarbon and carbon monoxide emissions:

Senator Muskie. $[\mathrm{I}] \mathrm{f}$ California feels that the oxides of nitrogen problem is so critical in Los Angeles County, that it ought to add this additional control should we preclude California from doing so?

Mr. Mann. Senator, my understanding is that the problem of preemption only arises where the Federal Government, the National Government, has established a standard, has occupied the area $\ldots . .57$

It therefore appears that states may regulate smoke emissions from new gasoline-powered vehicles, ${ }^{58}$ and that they may regulate other emissions, such as nitrogen oxides or lead, which are not now touched by federal standards.

\section{G. Installation of Additional Devices upon Transfer by the Original Purchaser}

A state requirement that additional devices be placed on a vehicle when it is sold by the original ultimate purchaser probably passes muster. The hearings are replete with references to the states' continued power over "used" vehicles; 59 and although "used" may have been intended by Congress to be a euphemism for "pre-1968," it is difficult to stretch the statutory pre-emption regarding "new" vehicles to include 1968 automobiles resold in 1970. The pre-emption may extend slightly beyond the precise statutory definition of "new" vehicles, in order to avoid an obvious circumvention of the statute by a state's regulation of the use of automobiles that are new in every sense except that they have been bought from the dealer.60 In light of the purpose of pre-emption and the language of the statute, it seems most appropriate to hold that a car is "new" only until it is transferred by the initial ultimate purchaser. It is true that initial sales may be slightly impeded by the possibility that the original owner may have to upgrade his pollution controls before reselling his car, but the impact that such a remote regulation would have upon the manufacturer is certainly not the problem that led Congress to enact the pre-emption provision.

\section{H. Limitations on Driving in Certain Areas}

It is clear that the federal law allows a state to provide that no private automobiles may be driven in certain areas. Such a state law

57. Senate Automotive Hearings, supra note 19 , at 1781 .

58. Such a regulation is found in InIinois AIr Pollution Control BoArd, Rules \& Regulations Governing the Control of Air Pollution ch. VI, § 6-5.1 (March 25, 1970).

59. See text accompanying notes 50-55 supra.

60. See text accompanying notes $42-43$ supra. 
might apply at all times or only during times of high carbon monoxide concentration. Even though this regulation would apply to vehicles with devices approved under federal law, it is exactly the type of provision for which the clause permitting state regulation was designed. Not only does such a regulation expressly deal with vehicle use rather than with emissions, but it does no violence to the spirit of the pre-emption section. Mr. Coston of HEW, who argued in favor of pre-emption, ${ }^{61}$ spoke about this specific situation:

I think it is perfectly appropriate for the local jurisdiction to take measures with respect to the use of automobiles which it might find necessary in order to protect the public health. If the problem is serious enough, for example, to restrict the use of the automobile within the area, I think the local community ought to do that. ${ }^{62}$

Moreover, the Senate report described the states' power over vehicle use as being "of particular importance. . . . It may be that, in some areas, certain conditions at certain times will require control of movement of vehicles .... These are areas in which the States and local government can be most effective."63

The same result follows whether the limitation on use takes the form of prohibition or of tolls or other charges. In either case state or local action would not offend any federal policy: No manufacturer would be required to build engines meeting varying standards; federal standards would not be duplicated; and the out-of-state driver would have no more difficulty in complying than would the local driver. That such a restriction might add to the cost of transportation cannot be decisive; virtually any state action against automotive pollution would have this effect, and yet not all state action is forbidden.

\section{Emission Limitations in Certain Areas}

Although a state may exclude all vehicles from designated areas, ${ }^{\text {os }}$ it is doubtful that it may exclude from such areas only those vehicles which emit more than a specified amount of carbon monoxide. Such a regulation is distinguishable from the regulation analyzed above because it differentiates among vehicles according to whether or not they comply with a standard more strict than the federal standard. With respect to pre-1968 vehicles, of course, such a distinction is perfectly acceptable since emissions from such vehicles

61. See text accompanying note 36 supra.

62. Senate Automotive Hearings, supra note 19 , at 115.

63. S. REP. No. 403, 90th Cong., 1st Sess. 34 (1967).

64. See text accompanying notes 61-63 supra. 
can be directly regulated. But with respect to new vehicles, such a regulation may be impermissible, because it has a very strong tendency to regulate emission controls even though it ostensibly regulates only vehicle use. The language of the federal prohibition-that "[n]o state . . . shall . . . attempt to enforce any standard relating to emissions" 05 - means that adverse consequences may not be attached to selling or operating noncomplying vehicles; and that result is precisely what the regulation considered here would accomplish. The adverse consequence in this instance is exclusion from areas where other vehicles are permitted to go. This case differs only in degree from a total ban on the use of noncomplying vehicles.

\section{J. The Prohibiting or Taxing of the Sale of Leaded Fuels}

Strictly speaking, limits on what goes into an engine are not limits on what comes out; and the legislative history with respect to older vehicles and use regulations recognized the principle that state action is usually not pre-empted on matters outside the scope of federal regulation. ${ }^{68}$

However, the 1967 Act did not ignore the subject of fuels; the Act contained a provision which requires the registration of fuel additives with the Secretary of HEW. ${ }^{67}$ That section says nothing about regulation of additives; and the purpose of the provision is only "to insure full access to the technical information needed to evaluate the possible health hazards of such materials. ..." 88 Nonetheless, the Senate committee also contemplated that the Secretary might, pursuant to his authority to set standards for emissions from new vehicles, take action against any additives found by him to be dangerous. ${ }^{69}$

Thus, it can be argued that because the Secretary of HEW can deal indirectly with lead additives by regulating lead emissions from new vehicles, the states are forbidden to regulate lead additives directly. Such an interpretation, however, would be an undue expansion of the pre-emptive language of the statute, since the states are forbidden only to regulate emissions. Moreover, the policies underlying federal pre-emption are inapplicable to fuel regulations. So long as leadless fuels can be satisfactorily consumed in ordinary vehicle

65. See text accompanying note 32 supra.

66. See text accompanying notes 50-55, 61-63 supra.

67. 42 U.S.C. \& 1857f-6b (Supp. IV, 1965-1968).

68. S. REP. No. 403, 90th Cong., 1st Sess. 35 (1967).

69. Id. 
engines, ${ }^{70}$ a fuel regulation imposes no burden on the automotive manufacturer, creates no duplication of present federal standards, and places no special burdens on out-of-state drivers. It may add to the expense of operating vehicles, but uniformity and freedom from multiple burdens appear to be the principal reasons for the preemption section, and the added expense seems minor in comparison with the states' obvious interest in regulating fuel content. ${ }^{71}$

\section{K. Prohibiting the Sale of Internal-Combustion Engines}

Prohibiting the sale of internal-combustion engines is not, strictly speaking, an emission regulation, since it neither restricts emissions nor conditions sale upon the attachment of emission control devices. Nonetheless, such a prohibition may have the same effect as prohibiting the sale of vehicles that do not meet a state emission standard. A similar case would arise if the state were to forbid the sale of gasoline, for again emissions that are permissible under federal standards would be affected by indirect regulation. Arguably both of these regulations are forbidden; a state prohibition on the sale of leaded gasoline-a permissible regulation-is distinguished only because lead emissions are not covered by current federal standards. ${ }^{72}$

Yet the impact of a total ban on the sale of internal-combustion engines is not precisely the same as the impact of an emission regulation. No manufacturer is required to meet multiple standards, because the product is excluded from the enacting state altogether. Moreover, internal-combustion engines are not made more expensive; they are taken off the market. Finally, there is no burden on out-of-state drivers since only sales are affected.

It is doubtful that just because mere regulation is forbidden, the more drastic tool of total exclusion is forbidden as well. In the case of highway billboards, for example, the federal government might well wish to ensure production efficiency by prescribing that all billboards in the nation be of standard sizes, colors, and types and that the states may not alter those standards. In such a situation, the policy of production efficiency would not be affected by a state's decision to ban billboards entirely, even though the state acts for the same reasons of aesthetics that led to the initial federal standards.

70. The leadless premium fuel now marketed on the East Coast can be used in most engines. See text accompanying note 14 supra. Merely leaving the lead out of present leaded fuels, however, might require engine modifications and thus complicate the legal question. See AIR \& WATER NEws, Feb. 16, 1970, at 2.

71. See text accompanying note 15 supra.

72. See text accompanying notes 66-70 supra. 
Prohibition of the sale of internal-combustion engines seems to fall within the same category.

\section{Prohibiting the Sale of Vehicles with Excessive Horsepower}

As in the case of a ban on internal-combustion engines, the purpose and effect of placing a maximum horsepower limit on automobiles may be to reduce emissions from new vehicles by limiting the amount of fuel consumed. Unlike the total ban, however, a horsepower limitation could conceivably be responsive to policies other than air pollution control. Larger vehicles place more of a burden on highway surfaces and take up more space in parking and in traffic. Furthermore, it can be argued that fuel savings are necessary for energy conservation. Thus, it is not necessarily clear from the regulation itself that its purpose is to regulate emissions, and the courts would probably refuse to investigate the motives of the legislature or agency that adopted the rule. One way to test the proposition is to ask whether existing license taxes which vary with horsepower are now unlawful merely because the higher tax has a slightly inhibitive effect upon the purchase of vehicles with high horsepower and thus with a high emission level. ${ }^{73}$ The answer is surely no, but not simply because the measure is a tax rather than a regulation; a differential tax based explicitly on emissions would clearly be pre-empted. Therefore, the remote impact of a horsepower distinction upon emissions and the existence of justifications for that distinction other than air pollution control would allow the horsepower provision to be upheld in either case.

\section{Conclusion}

The conclusions suggested in this Article are tentative; so far as I know, no court has yet decided any of the hypothetical cases discussed. A recent decision of the United States Court of Appeals for the Second Circuit, however, has given encouragement to a narrow reading of the pre-emption provision. ${ }^{74}$ That case involved the National Traffic and Motor Vehicle Safety Act, which contains a provision forbidding state regulation of an item that is covered, with respect to the "same aspect of performance," by federal safety standards. ${ }^{75}$ A federal standard permitting optional headlights that do not impair "the effectiveness of the required equipment" was con-

\footnotetext{
73. Such provisions are fairly common. See, e.g., IlL. ANN. STAT. ch. 95 1/2, § 3-806 (Smith-Hurd 1970).

74. Chrysler Corp. v. Tofany, 419 F.2d 499 (2d Cir. 1969).

75. 15 U.S.C. \& 1392(d) (Supp. IV, 1965-1968).
} 
strued to refer only to the effect of such headlights on the vision of the driver whose car is equipped with the optional lights, and not to their effect on drivers of other vehicles: "If traffic safety is furthered by a traditional type of state regulation .... a narrow construction of the pre-emptive effect of the federal Act and standard . . . is required."76

What the states ought to do about automobile pollution is a difficult question. The essential point of this Article is simply that the states should be given a fair chance to deal with the problem. Pre-emption is a disgrace.

Yet there is much the states can presently do, and consequently pre-emption is not an excuse for total inaction. Among the more promising avenues open now are restrictions on use, taxes on the sale of leaded fuels, and the establishment of rapid transit. Additional legislation will probably be necessary if these avenues are to be pursued; the time to seek it is now.

76. 419 F.2d at 511 . 